\title{
PENGARUH MODEL LEARNING CYCLE TERHADAP HASIL BELAJAR IPA
}

\author{
Agus Jatmiko ${ }^{1)}$ \\ 1) Universitas Islam Negeri Raden Intan Lampung e-mail: agusjatmiko@ radenintan.ac.id
}

Diterima: 22 Mei 2017. Disetujui : 19 Juni 2017. Dipublikasikan: 29 Juni 2017

\begin{abstract}
Abstrak: Tujuan penelitian ini adalah untuk mengetahui pengaruh model pembelajaran dan konsep diri terhadap hasil belajar IPA. Penelitian eksperimen ini dilakukan di SMP Negeri 24 Kota Bandar Lampung dengan rancangan faktorial 2x2. Hasil penelitian ini adalah sebagai berikut: 1) hasil belajar IPA kelompok siswa yang belajar dengan model Learning Cycle lebih tinggi daripada kelompok siswa yang belajar dengan model Contextual Teaching and Learning; 2) ada pengaruh interaksi antara model pembelajaran dan konsep diri terhadap hasil belajar IPA; 3) pada kelompok yang memiliki konsep diri positif, hasil belajar IPA siswa yang belajar menggunakan model Learning Cycle lebih tinggi dari siswa yang belajar menggunakan model Contextual Teaching and Learning; dan 4) pada kelompok yang memiliki konsep diri negatif, hasil belajar IPA siswa yang belajar dengan model Learning Cycle lebih rendah dari siswa yang belajar dengan model Contextual Teaching and Learning.
\end{abstract}

Kata kunci: hasil belajar IPA, konsep diri, Learning Cycle

\section{PENDAHULUAN}

Produk pendidikan yang baik diperoleh melalui proses pembelajaran yang baik pula (Widhy, 2012). Pembelajaran lebih bermakna apabila dalam proses pembelajaran berorientasi pada keterlibatan siswa secara aktif dengan model pembelajaran yang dapat memberikan kesempatan untuk mengembangkan kreativitas dan aktivitas belajar. dalam proses pembelajaran diperlukan sebuah model pembelajaran yang tidak hanya mengulang kembali ide-ide, tetapi pembelajaran yang mampu mengeksplorasi ide-ide siswa sebagai pebelajar. Hal ini dimaksudkan agar siswa bisa mendapatkan pembelajaran yang lebih bermakna bagi mereka.

Selama ini keadaan yang berlangsung di lapangan bukan sebagaimana yang diharapkan. Pembelajaran IPA di sekolah untuk meningkatan hasil belajar siswa secara optimal belum dilaksanakan secara sistematis, berpola, dan terarah. Minimnya kreativitas guru untuk menciptakan atmosfer pembelajaran yang dapat mengarahkan siswa agar mampu mengkonstruksi pengalaman kehidupan seharihari dengan konstruksi pengetahuan dalam pembelajaran di dalam kelas. Fenomena kurang keberhasilan pencapaian tujuan pembelajaran khususnya dalam meningkatkan hasil belajar IPA siswa, disebabkan siswa kurang diperlakukan sebagai bagian dari realitas dunia mereka dalam pembelajaran di dalam kelas.

Alasan ini diperkuat dengan hasil observasi di SMP Negeri 24 Kota Bandar Lampung sebelum penelitian dilakukan. Menurut pengamatan bahwa pembelajaran IPA di sekolah tersebut model pembelajaran konvensional di kelas masih dominan. Tidak sedikit masih dijumpai siswa kurang diberi kesempatan untuk mengkonstruk pengetahuannya sendiri. Selain itu, hasil ujian akhir semester pelajaran IPA klas VIII prestasi belajar ini masih jauh untuk memenuhi batas atau kriteria ketuntasan minimal (KKM) yang ditetapkan oleh sekolah, yaitu sebesar 70. 
Ada beberapa faktor yang menjadi penghambat pencapaian hasil belajar IPA, secara garis besar dapat dikelompokkan menjadi tiga faktor, yaitu: (1) minimnya pengetahuan dan pemahaman guru dalam mengembangkan modelmodel pembelajaran, (2) karakteristik siswa yang belum terakomodasi dengan baik dalam pembelajaran dan kurangnya rasa percaya diri dalam memberikan hipotesis terhadap suatu peristiwa yang berkaitan dengan IPA, dan (3) guru kurang maksimal memanfaatkan potensi lingkungan sebagai media dan sumber belajar.

Pengembangan berpikir konstruktivisme pada pelajaran IPA dapat dilakukan dengan menggunakan model pembelajaran yang memungkinkan siswa mengeksplorasi alam, kemudian melalui pemikiran yang mereka tumbuhkan, eksplorasi tersebut menjadi data-data yang bermakna untuk dirangkai menjadi pengetahuan baru. Model pembelajaran yang diduga dapat meningkatkan prestasi atau hasil belajar tersebut adalah dengan menggunakan model pembelajaran Learning Cycle. Dugaan tersebut berakar dari fase-fase yang ada pada model pembelajaran Learning Cycle, terdiri atas exploration phase, concept introduction phase, concept application phase (Carin, 1993). Selanjutnya dari setiap fase tersebut memungkinkan siswa untuk terlibat secara aktif baik mental maupun fisik selama mengikuti pembelajaran.

Di samping model pembelajaran, karakteristik siswa yang baik seperti persepsi atau pandangan mereka atas dirinya sendiri sebagai suatu konsep diri secara positip terhadap pelajaran yang dipelajarinya maka hal ini dapat menunjang keberhasilan siswa belajar.

Selain model pembelajaran Learning Cycle seperti tersebut di atas dapat digunakan model pembelajaran lain yang hampir sama dan juga berakar pada pandangan teori belajar konstruktivisme, yaitu dengan menggunakan model pembelajaran Contextual Teaching and Learning. Pembelajaran Contextual Teaching and Learning menekankan pada aktivitas siswa untuk belajar dengan mengedepankan keterkaitan materi dan keadaan kehidupan nyata. Dengan demikian dapat dipahami bahwa setiap model pembelajaran yang sudah dipilih guru dengan berbagai komponennya juga berpotensi untuk dapat digunakan dalam meningkatkan kualitas pembelajarannya.

Selanjutnya, pembelajaran dengan model Learning Cycle diharapkan dapat memberikan perbedaan hasil belajar yang akan dilakukan dengan penelitian ekperimen yaitu dengan membandingkan rata-rata hasil belajar siswa pada pelajaran IPA dengan menggunakan model pembelajaran Contextual Teaching and Learning yang dilakukan secara bersamaan pada kelas yang berbeda.

Secara umum penelitian ini bertujuan untuk mengetahui pengaruh model pembelajaran dan konsep diri terhadap hasil belajar IPA. Secara khusus tujuan penelitian ini adalah untuk menjawab permasalahan yang berkaitan dengan model pembelajaran dan konsep diri terhadap hasil belajar IPA. Adapun rincian tujuan penelitian ini adalah untuk mengetahui:

1. Perbedaan hasil belajar IPA antara siswa yang belajar dengan model Learning Cycle dan siswa yang belajar dengan model Contextual Teaching and Learning.

2. Pengaruh interaksi antara model pembelajaran dan konsep diri siswa terhadap hasil belajar IPA. 
3. Perbedaan hasil belajar IPA antara siswa yang belajar dengan model Learning Cycle dan siswa yang belajar dengan model Contextual Teaching and Learning pada kelompok siswa yang memiliki konsep diri positif.

4. Perbedaan hasil belajar IPA antara siswa yang belajar dengan model Learning Cycle dan siswa yang belajar dengan model Contextual Teaching and Learning pada kelompok siswa yang memiliki konsep diri negatif.

\section{METODE}

Penelitian ini menggunakan metode eksperimen dengan disain treatment by level $2 \times 2$. Variabel penelitian terdiri dari satu variabel terikat, yaitu hasil belajar IPA dan dua variabel bebas, yaitu model pembelajaran sebagai variabel perlakuan serta konsep diri sebagai variabel atribut. Variabel model pembelajaran terdiri dari dua model, yaitu model pembelajaran Learning Cycle dan model pembelajaran Contextual Teacher and Learning, sedangkan variabel atribut konsep diri terbagi menjadi konsep diri positif dan konsep diri negatif. Desain eksperimen penelitian disajikan dalam bentuk kontelasi penelitian sehingga dapat memberikan gambaran untuk menguji efektivitas perlakuan dalam eksperimen. Selanjutnya, konstelasi penelitian dapat ditunjukkan pada Tabel 1 berikut ini.

Tabel 1. Rancangan Eksperimen (Disain Treatment by Level 2X2)

\begin{tabular}{cccc}
\hline & & \multicolumn{2}{c}{$\begin{array}{c}\text { Variabel Perlakuan } \\
\text { Variabel Atribut }\end{array}$} \\
\cline { 3 - 4 } & & $\begin{array}{c}\text { Model } \\
\text { Learning Cycle } \\
\left(\mathrm{A}_{1}\right)\end{array}$ & $\begin{array}{c}\text { Model } \\
\text { Contextual Teacher and } \\
\text { Learning } \\
\left(\mathrm{A}_{2}\right)\end{array}$ \\
\hline \multirow{2}{*}{$\begin{array}{c}\text { Konsep diri } \\
(\mathrm{B})\end{array}$} & $\begin{array}{c}\text { Konsep diri positif } \\
\left(\mathrm{B}_{1}\right)\end{array}$ & $\left(\mathrm{A}_{1} \mathrm{~B}_{1}\right)$ & $\left(\mathrm{A}_{2} \mathrm{~B}_{1}\right)$ \\
\cline { 2 - 4 } & $\mathrm{K}$ & & \\
& $\left(\mathrm{B}_{2}\right)$ & $\left(\mathrm{A}_{1} \mathrm{~B}_{2}\right)$ & $\left(\mathrm{A}_{2} \mathrm{~B}_{2}\right)$ \\
\hline
\end{tabular}

Keterangan:

$\mathrm{A}_{1} \quad$ : Kelompok siswa yang belajar menggunakan model Learning Cycle.

$\mathrm{A}_{2} \quad$ : Kelompok siswa yang belajar menggunakan model Contextual Teacher and Learning.

$\mathrm{B}_{1} \quad$ : Kelompok siswa yang memiliki konsep diri positif.

$\mathrm{B}_{2} \quad$ : Kelompok siswa yang memiliki konsep diri negatif.

$A_{1} B_{1} \quad$ : Kelompok siswa yang memiliki konsep diri positif yang belajar menggunakan model Learning Cycle.

$\mathrm{A}_{2} \mathrm{~B}_{1} \quad$ : Kelompok siswa yang memiliki konsep diri positif yang belajar menggunakan model Contextual Teacher and Learning.

$A_{1} B_{2} \quad$ : Kelompok siswa yang memiliki konsep diri negatif yang belajar menggunakan model Learning Cycle. 
$\mathrm{A}_{2} \mathrm{~B}_{2} \quad$ : Kelompok siswa yang memiliki konsep diri negatif yang belajar menggunakan model Contextual Teacher and Learning.

Populasi target dalam penelitian ini adalah seluruh siswa SMP Negeri 24 Kota Bandar Lampung, dan populasi terjangkau dalam penelitian ini adalah seluruh siswa kelas VIII SMP Negeri 24 Kota Bandar Lampung. Teknik pengambilan sampel dilakukan secara multistage random sampling. Kelompokkelompok siswa yang teridentifikasi berdasarkan koesioner tentang konsep diri tersebut selanjutnya ditetapkan sebagai unit analisis pada penelitian ini dan dapat dideskripsikan pada Tabel 2 berikut.

Tabel 2. Komposisi Subjek Penelitian

\begin{tabular}{cccc}
\hline & \multicolumn{2}{c}{ Model Pembelajaran } & Jumlah \\
\cline { 2 - 3 } Konsep diri & Learning Cycle & $\begin{array}{c}\text { Contextual Teacher and } \\
\text { Learning }\end{array}$ & \\
\cline { 2 - 3 } Positif & 11 orang & 11 orang & 22 orang \\
\hline Negatif & 11 orang & 11 orang & 22 orang \\
\hline
\end{tabular}

Teknik pengumpulan data pada penelitian ini menggunakan dua instrumen, yaitu instrumen tes mengenai hasil belajar IPA dan instrumen kuesioner mengenai konsep diri siswa. Hasil belajar IPA dapat didefinisikan sebagai skor yang diperoleh siswa dalam menjawab butir-butir soal yang diberikan untuk mengukur kemampuan pada kawasan atau ranah. Konsep diri adalah skor yang diperoleh seorang siswa mengenai pandangan dirinya terhadap kompetensi akademik dan non akademik yang dimiliki.

Analisis data yang digunakan dalam penelitian ini menggunakan statistika deskriptif dan statistika inferensial. Untuk teknik analisis data yang digunakan dalam penelitian ini adalah teknik analisis varians (ANAVA) dua jalan. Anava dua jalan digunakan untuk menguji variabel model pembelajaran dan variabel konsep diri. Apabila hasil analisis data menujukkan adanya pengaruh interaksi antara model pembelajaran dan komsep diri terhadap hasil belajar IPA, maka analisis dapat dilanjutkan dengan menggunakan uji Tukey dengan maksud untuk melihat efek interaksi atau efek sederhana mana yang lebih unggul (Murwani, 2005).

\section{Hipotesis Statistik}

Hipotesis pertama:

$$
\begin{array}{ll}
\mathrm{H}_{\mathrm{O}} & : \boldsymbol{\mu} \mathrm{A}_{1} \leq \boldsymbol{\mu} \mathrm{A}_{2} \\
\mathrm{H}_{1} & : \boldsymbol{\mu} \mathrm{A}_{1}>\boldsymbol{\mu} \mathrm{A}_{2}
\end{array}
$$

Hipotesis kedua:

$$
\begin{aligned}
& \mathrm{H}_{\mathrm{O}} \quad \text { : Interaksi A X B }=0 \\
& \mathrm{H}_{1} \text { : Interaksi A X B } \neq 0
\end{aligned}
$$

Hipotesis ketiga:

$$
\begin{array}{ll}
\mathrm{H}_{\mathrm{O}} & : \mu \mathrm{A}_{1} \mathrm{~B}_{1} \leq \mu \mathrm{A}_{2} \mathrm{~B}_{1} \\
\mathrm{H}_{1} & : \mu \mathrm{A}_{1} \mathrm{~B}_{1}>\mu \mathrm{A}_{2} \mathrm{~B}_{1}
\end{array}
$$

Hipotesis keempat:

$$
\begin{array}{ll}
\mathrm{H}_{\mathrm{O}} & : \mu \mathrm{A}_{1} \mathrm{~B}_{2} \geq \mu \mathrm{A}_{2} \mathrm{~B}_{2} \\
\mathrm{H}_{1} & : \mu \mathrm{A}_{1} \mathrm{~B}_{2} \square \mu \mathrm{A}_{2} \mathrm{~B}_{2}
\end{array}
$$


Keterangan:

$\mathrm{H}_{\mathrm{o}} \quad$ : Hipotesis nol.

$\mathrm{H}_{1} \quad$ : Hipotesis alternatif.

$\mu_{\mathrm{A}_{1}} \quad$ : Rata-rata hasil belajar IPA siswa yang belajar menggunakan model pembelajaranLearning Cycle.

$\mu_{\mathrm{A}_{2}}$ : Rata-rata hasil belajar IPA siswa yang belajar menggunakan model pembelajaran Contextual Teaching and Learning.

$\mu_{A_{1} B_{1}} \quad$ : Rata-rata hasil belajar IPA kelompok siswa yang memiliki konsep diri positif yang belajar dengan model pembelajaran Learning Cycle.

$\mu_{A_{2} B_{1}}$ : Rata-rata hasil belajar IPA kelompok siswa yang memiliki konsep diri positif yang belajar dengan model pembelajaran Contextual Teaching and Learning.

$\mu_{A_{1} B_{2}}$ : Rata-rata hasil belajar IPA kelompok siswa yang memiliki konsep diri negatif yang belajar dengan model pembelajaran Learning Cycle.

$\mu_{\mathrm{A}_{2} \mathrm{~B}_{2}}$ : Rata-rata hasil belajar IPA kelompok siswa yang memiliki konsep diri negatif yang belajar dengan model pembelajaran Contextual Teaching and Learning.

\section{HASIL PENELITIAN}

Pengujian hipotesis penelitian ini dilakukan dengan teknik analisis varians (ANAVA) dua jalan, yaitu analisis varians untuk desain penelitian yang mempunyai dua variabel bebas atau lebih yang selanjutnya dapat disebut Anava ganda atau Anava faktorial (Winarsunu, 2007).

Apabila hasil analisis data menunjukkan adanya pengaruh interaksi antara model pembelajaran dan konsep diri terhadap hasil belajar IPA, maka analisis dapat dilanjutkan dengan menggunakan Uji Tukey dengan maksud untuk melihat efek interaksi atau efek sederhana mana yang lebih unggul (Murwani, 2005). Hasil perhitungan yang diperoleh dapat dirangkum pada Tabel 3 berikut ini.

Tabel 3. Rangkuman Hasil ANAVA Pengaruh Model Pembelajaran dan Konsep Diri terhadap Hasil Belajar IPA

\begin{tabular}{|c|c|c|c|c|c|c|c|}
\hline \multirow{2}{*}{$\begin{array}{l}\text { Sumber } \\
\text { Varians }\end{array}$} & \multirow{2}{*}{ JK } & \multirow{2}{*}{ Db } & \multirow{2}{*}{$\begin{array}{c}\text { RJK }=J K / \\
\text { Db }\end{array}$} & \multirow{2}{*}{$\begin{array}{r}\text { F }_{\text {hitung }}= \\
\text { RJK/DK }\end{array}$} & \multicolumn{2}{|c|}{$\mathbf{F}_{\text {tabel }}$} & \multirow{2}{*}{ Keterangan } \\
\hline & & & & & $\alpha=0,05$ & $\alpha=0,01$ & \\
\hline A & 93,09 & 1 & 93,09 & 5,22 & 4,08 & 7,32 & Signifikan \\
\hline B & 1859 & 1 & 1859 & 104,20 & 4,08 & 7,32 & Signifikan \\
\hline $\mathrm{AB}$ & 626,27 & 1 & 626,27 & 35,10 & 4,08 & 7,32 & Signifikan \\
\hline $\mathrm{AK}$ & 2578,36 & 3 & 859,45 & - & - & - & - \\
\hline DK & 713,64 & 40 & 17,84 & - & - & - & - \\
\hline $\mathrm{TR}$ & 3292 & 43 & - & - & - & - & - \\
\hline
\end{tabular}


Keterangan:

JK : Jumlah Kuadrat Sumber Varians

$\mathrm{Db} \quad$ : Ferajat Bebas Sumber Varians

RJK : Rata-rata Jumlah Kuadrat Sumber Varians

DK : Jumlah Kuadrat Dalam Kelompok

Berdasarkan analisis varians (ANAVA) yang ditampilkan pada Tabel 3 di atas dapat dilakukan pengujian hipotesis sebagai berikut:

1. Hipotesis pertama: Hasil belajar IPA kelompok siswa yang belajar dengan model Learning Cycle lebih tinggi daripada kelompok siswa yang belajar dengan Model Contextual Teaching and Learning.

Berdasarkan hasil perhitungan yang dirangkum pada tabel Anava diperoleh nilai $F_{\text {hitung }}=5,22$ sedangkan $F_{\text {tabel }}=4,08(\alpha=0,05)$ maka $F_{\text {hitung }}$ $>F_{\text {tabel }}$ baik pada taraf signifikani 0,05 sehingga $H_{0}$ ditolak. Dengan demikian dapat disimpulkan bahwa terdapat perbedaan rata-rata hasil belajar IPA kelompok siswa yang belajar dengan model Learning Cycle dan kelompok siswa yang belajar dengan model Contextual Teaching and Learning.

Untuk mengetahui kelompok yang lebih tinggi hasil belajar IPA dapat dilakukan dengan melihat nilai rata-rata kedua kelompok. Kelompok siswa yang belajar dengan menggunakan model Learning Cycle, rata-rata hasil belajar IPA sebesar 24,45 sedangkan kelompok siswa yang belajar dengan menggunakan model Contextual Teaching and Learning rata-rata sebesar 21,55. Selanjutnya dapat disimpulkan bahwa hasil belajar IPA kelompok siswa yang belajar dengan menggunakan model Learning Cycle lebih baik daripada hasil belajar IPA kelompok siswa yang belajar dengan menggunalan model Contextual Teaching and Learning.

2. Hipotesis kedua: Terdapat pengaruh interaksi model pembelajaran dan konsep diri terhadap hasil belajar IPA.

Berdasarkan hasil perhitungan yang dirangkum pada tabel Anava diperoleh nilai $F_{\text {hitung }}=35,10$ sedangkan $F_{\text {tabel }}=4,08(\alpha=0,05)$ dan 7,32 $(\alpha=$ 0,01) maka $F_{\text {hitung }}>F_{\text {tabel }}$ baik pada taraf signifikani 0,05 maupun 0,01 sehingga $H_{0}$ ditolak. Selanjutnya dapat disimpulkan bahwa terdapat pengaruh interaksi antara model pembelajaran dan konsep diri siswa terhadap hasil belajar IPA.

Tabel 4. Rangkuman Hasil Perhitungan Uji Tukey

\begin{tabular}{|c|c|c|c|c|}
\hline \multirow{2}{*}{ No } & \multirow{2}{*}{ Kelompok } & \multirow{2}{*}{$\mathbf{Q}_{\text {hitung }}$} & \multicolumn{2}{|c|}{$\mathbf{Q}_{\text {tabel }}$} \\
\hline & & & $\overline{\mathbf{a}}=0,05$ & $\overline{\mathbf{a}}=0,01$ \\
\hline 1 & $\mathrm{~A}_{1}$ dan $\mathrm{A}_{2}$ & 3,22 & 2,95 & 4,02 \\
\hline 2 & $\mathrm{~A}_{1} \mathrm{~B}_{1}$ dan $\mathrm{A}_{2} \mathrm{~B}_{1}$ & 8,21 & 3,11 & 4,39 \\
\hline 3 & $\mathrm{~A}_{1} \mathrm{~B}_{2}$ dan $\mathrm{A}_{2} \mathrm{~B}_{2}$ & 3,64 & 3,11 & 4,39 \\
\hline
\end{tabular}


Berkenaan dengan terbuktinya hipotesis penelitian yang menyatakan adanya interaksi antara model pembelajaran dan konsep diri terhadap hasil belajar IPA, maka analisis dilanjutkan dengan uji lanjut yaitu uji Tukey yang selanjutnya digunakan untuk pengujian hipotesis ketiga dan keempat. Berdasarkan hasil perhitungan uji Tukey dapat dirangkum pada Tabel 4 diatas.

3. Hipotesis ketiga: Kelompok siswa yang memiliki konsep diri positif, hasil belajar IPA yang menggunakan model Learning Cycle lebih tinggi daripada hasil belajar yang menggunakan model Contextual Teaching and Learning.

Berdasarkan perhitungan statistik uji Tukey pada tabel 4.10 yang menunjukkan nilai $Q_{\text {hitung }}=8,21$ dan nilai $Q_{\text {tabel }}=3,11(\alpha=0,05)$ dan 4,39 $(\alpha$ $=0,01)$ maka $Q_{\text {hitung }}>Q_{\text {tabel }}$ baik pada taraf signifikani 0,05 maupun 0,01 sehingga $H_{0}$ ditolak. Selanjutnya dapat disimpulkan terdapat perbedaan rata-rata hasil belajar IPA pada kelompok siswa yang memiliki konsep diri positif antara yang belajar dengan model Learning Cycle dan yang belajar dengan model Contextual Teaching and Learning.

Untuk mengetahui kelompok yang lebih tinggi hasil belajar IPA dapat dilakukan dengan melihat nilai rata-rata kedua kelompok. Kelompok siswa yang belajar dengan menggunakan model Learning Cycle, rata-rata hasil belajar IPA sebesar 34,73 sedangkan kelompok siswa yang belajar dengan menggunakan model Contextual Teaching and Learning rata-rata sebesar 24,27.

Selanjutnya dapat disimpulkan bahwa bagi kelompok siswa yang memiliki konsep diri positif, hasil belajar IPA yang belajar menggunakan model Learning Cycle lebih baik daripada hasil belajar IPA kelompok siswa yang belajar menggunakan model Contextual Teaching and Learning.

4. Hipotesis keempat: Kelompok siswa yang m emiliki konsep diri negatif, hasil belajar IPA yang belajar dengan model Contextual Teaching and Learning lebih tinggi daripada yang belajar dengan model Learning Cycle.

Berdasarkan perhitungan statistik uji Tukey pada tabel 4.10 yang menunjukkan nilai $Q_{\text {hitung }}=3,64$ dan nilai $Q_{\text {tabel }}=3,11(\alpha=0,05)$ maka $Q_{\text {hitung }}>Q_{\text {tabel }}$ pada taraf signifikani 0,05 sehingga $H_{0}$ ditolak. Sehingga disimpulkan terdapat perbedaan rata-rata hasil belajar IPA pada kelompok siswa yang memiliki konsep diri negatif antara yang belajar dengan model pembelajaran Learning Cycle dan yang belajar dengan model Contextual Teaching and Learning. Dalam hal ini rata-rata skor hasil belajar IPA siswa yang memiliki konsep diri negatif pada pembelajaran dengan model Contextual Teaching and Learning lebih tinggi dibandingkan siswa pada pembelajaran dengan model Learning Cycle.

Untuk mengetahui hasil belajar IPA bagi kelompok siswa yang memiliki konsep diri negatif dapat dilakukan dengan melihat nilai rata-rata kedua kelompok model pembelajaran yang digunakan. Kelompok siswa yang belajar dengan menggunakan model Contextual Teaching and Learning rata-rata hasil belajar IPA sebesar 18,82 sedangkan kelompok siswa yang belajar dengan menggunakan model Learning Cycle rata-rata sebesar 14,18. Selanjutnya dapat disimpulkan bahwa bagi kelompok siswa yang memiliki konsep diri negatif, hasil belajar IPA 
yang belajar dengan menggunakan model pembelajaran Contextual Teaching and Learning lebih baik daripada hasil belajar IPA kelompok siswa yang belajar dengan menggunakan model pembelajaran Learning Cycle.

\section{PEMBAHASAN}

\section{Hasil Belajar IPA Kelompok Siswa Menggunakan Model Learning Cycle Lebih Tinggi dari Kelompok Siswa Menggunakan Model Contextual Teaching and Learning.}

Hasil pengujian hipotesis membuktikan bahwa terdapat perbedaan hasil belajar IPA antara kelompok siswa yang belajar dengan model Learning Cycle dan kelompok siswa yang belajar dengan model Contextual Teaching and Learning. Hasil belajar IPA pada kelompok siswa yang belajar yang diberi perlakuan pembelajaran dengan model Learning Cycle lebih baik daripada hasil belajar IPA kelompok siswa yang belajar dengan model Contextual Teaching and Learning. Hal ini memberikan makna bahwa pemberian perlakuan model pembelajaran Learning Cycle yang dilakukan dalam penelitian ini dapat meningkatkan hasil belajar IPA siswa.

Peningkatan hasil belajar IPA pada kelompok siswa yang belajar dengan model pembelajaran Learning Cycle antara lain disebabkan oleh adanya tahaptahap kegiatan atau fase di dalam pembelajaran model Learning Cycle. Selain itu perbedaan hasil belajar IPA juga diperkuat oleh adanya variasi pendekatan atau meode yang diterapkan dalam suatu rencana pembelajaran yang menggunakan model Learning Cycle. Guru dalam setiap tahap penyampaian materi dapat menggunakan berbagai pendekatan dan metode dalam satu waktu yang mampu memperkaya pengalaman belajar siswa. Penggunaan berbagai pendekatan dan metode dalam pembelajaran dapat menjadikan siswa lebih mandiri dan senang untuk belajar. Penerapan pendekatan dan metode yang bervariasi dalam model Learning Cycle akan membantu siswa dalam memahami dan mengingat materi pelajaran karena dalam teori kognitif yang disampaikan Gagne dalam Suyono dan Hariyanto (2011) menyatakan bahwa dalam pembelajaran terjadi proses tranfer informasi yang selanjutnya diolah sehingga menghasilkan keluaran berupa hasil belajar.

Sedangkan pada Contextual Teaching and Learning guru memulai pembelajaran dengan sajian atau tanya jawab lisan yang terkait dengan dunia nyata kehidupan siswa. Ada kalanya kemampuan atau pengetahuan awal belajar siswa yang masih rendah, serta pengalaman siswa sebatas pada hal-hal yang mereka ketahui, maka model Contextual Teaching and Learning ini terasa kurang bermanfaat yang pada akhirnya membuat motivasi belajar yang timbul pada diri siswa kurang maksimal, proses pemberian materi yang disajikan menjadi lambat sehingga siswa kurang memahami dengan baik, akhirnya model pembelajaran yang mengharapkan agar diperoleh pengetahuan sesuai dengan kehidupan nyata siswa belum tercapai secara maksimal.

Model Learning Cycle akan lebih memberikan rangsangan bagi siswa untuk dapat lebih memiliki kemampuan yang lebih tinggi dalam memahami apa yang harus dilakukan dalam setiap aspek kegiatan pembelajaran yang diberikan, bermakna dan dapat terakumulasi dengan baik dalam proses pembelajaran, akan memberikan konsep-konsep yang baik dan benar dalam mempelajari materi IPA. 
Hal ini membuktikan bahwa model pembelajaran Learning Cycle dapat membantu atau meningkatkan dalam pencapaian hasil belajar siswa.

Berdasar kenyataan empiris yang telah ditemukan dalam penelitian ini telah mendukung kebenaran teoritis bahwa model pembelajaran Learning Cycle dapat menjadi salah satu model yang efektif untuk diterapkan dalam meningkatkan hasil belajar IPA.

\section{Pengaruh Interaksi antara Model Pembelajaran dan Konsep Diri terhadap Hasil Belajar IPA}

Berdasarkan analisis statistik mengenai hasil belajar IPA yang saling dipengaruhi oleh dua variable bebas dalam penelitian ini, yaitu model pembelajaran dan konsep diri menunjukkan adanya pengaruh interaksi. Hasil penelitian ini selanjutnya menunjukkan bahwa model pembelajaran dan konsep diri siswa sangat mempengaruhi dan turut menentukan keberhasilan siswa dalam memperoleh hasil belajar IPA yang lebih baik. Adanya pengaruh interaksi ini membuktikan bahwa masing-masing model pembelajaran akan memberikan pengaruh yang berbeda terhadap hasil belajar IPA jika diperlakukan pada kelompok siswa yang memiliki tingkat konsep diri yang berbeda pula.

Pada model pembelajaran Learning Cycle, konsep diri positif mampu memberi efek kontribusi terhadap peningkatan hasil belajar IPA. Efek ini disebabkan oleh pandangan diri mereka sendiri secara positif atau keyakinan mereka yang tinggi terhadap kemampuan tentang fisik, psikologis serta pengetahuan akademis dari kelompok siswa terutama yang memiliki konsep diri positif. Sedangkan pada model pembelajaran Contextual Teaching and Learning siswa yang memiliki konsep diri positif kurang memberi kontribusi dengan baik. Hal ini dapat terjadi karena model Contextual Teaching and Learning kurang memberi peluang kepada siswa untuk berfikir melalui tahapan belajar secara bertahap sehingga menyebabkan siswa yang memiliki konsep diri positif menjadi kurang aktif hanya mengutamakan prinsip atau indikator pembelajaran saja, yang akhirnya berimplikasi terhadap tingkat daya nalar siswa yang kurang maksimal.

Selanjutnya konsep diri negatif pada penerapan model Learning Cycle kurang memberi pengaruh yang lebih baik, hal ini disebabkan oleh karakteristik model Learning Cycle memerlukan pembelajaran yang sistematis, menggunakan fakta dan konsep, serta proses berfikir siswa secara bertahap sampai dengan penerapan konsep. Sedangkan pada model Contextual Teaching and Learning aktivitas guru masih terasa nampak dengan keikutsertaaan guru sebagai pembimbing berusaha membantu dalam pemecahan masalah terutama bagi siswa yang memiliki pengetahuan atau kemampuan awal yang masih rendah sehingga siswa merasa lebih nyaman belajar dengan pola tersebut. Kenyamanan ini dapat mempengaruhi pengetahuan yang mereka miliki sehingga dapat digunakan dengan mudah saat proses berfikir.

Penjelasan di atas mengungkapkan bahwa konsep diri pada diri siswa merupakan bagian dari kemampuan rasa percaya diri mereka saat menerima pembelajaran, maka akan mempengaruhi tingkat keberhasilan belajarnya. Hal ini sesuai sebagaimana yang dijelaskan oleh Woolfolk (2004) yang menyatakan bahwa orang yang memiliki rasa percaya yang kuat tentang kemampuan dirinya 
akan berusaha keras untuk melaksanakan tugas yang menantangnya apabila dibandingkan dengan orang-orang yang meragukan kemampuaan dirinya.

\section{Siswa yang Memiliki Konsep Diri Positif, Hasil Belajar IPA dengan Model Learning Cycle Lebih Tinggi dari Model Contextual Teaching and Learning.}

Hasil pengujian hipotesis ketiga menunjukkan bahwa pada kelompok siswa yang memiliki konsep diri positif, skor rata-rata hasil belajar IPA kelompok siswa yang belajar dengan model Learning Cycle dan kelompok siswa yang belajar dengan model Contextual Teaching and Learning berbeda secara signifikan.

Perbedaan mendasar model Learning Cycle dengan model Contextual Teaching and Learning adalah pada model Learning Cycle yaitu terdapat proses pembelajaran yang dilaksanakan melalui fase atau tahapan-tahapan dimana setiap fase menggambarkan tingkat kemampuan berfikir siswa sebagai dasar kemampuan untuk mempersiapkan pengetahuan yang akan dipelajari selanjutnya. Pada fase pembangkitan minat tujuannya adalah memotivasi kesiapan belajar dan juga untuk mengetahui tingkat pengetahuan awal belajar siswa. Hal ini memungkinkan proses pembelajaran akan lebih efektif untuk mencapai tujuan pembelajaran terutama bagi siswa yang memiliki konsep diri positif. Bagi siswa yang memiliki konsep diri positif proses belajar tersebut menjadi suatu pembelajaran yang lebih menyenangkan dan menarik sehingga pembelajaran di kelas akan lebih bermakna.

Hal lain yang mempengaruhi pencapaian hasil belajar IPA bagi siswa yang memiliki konsep diri positif bahwa pembelajaran dengan model Learning Cycle adalah kesiapan mereka untuk meningkatkan kemampuan, optimis, rasional serta mempunyai rasa tanggung jawab dalam menerima materi pembelajaran serta menghadapi tugas-tugas yang diberikan dengan baik sehingga pencapaian hasil belajar IPA yang lebih tinggi dapat terwujud. Sebaliknya, pada model Contextual Teaching and Learning tidak didapatkan fase pembelajaran atau tahapan belajar seperti pada model Learning Cycle. Karena pembelajaran Contextual Teaching and Learning lebih menekankan pada indikator dan prinsip pembelajaran yang berdasarkan pada konteksnya dalam kehidupan nyata.

\section{Siswa yang Memiliki Konsep Diri Negatif, Hasil Belajar IPA dengan Model Contextual Teaching and Learning Lebih Tinggi dari Model Learning Cycle.}

Hasil analisis pengujian hipotesis menunjukkan bahwa skor rata-rata hasil belajar IPA pada kelompok siswa yang belajar menggunakan model Contextual Teaching and Learning dibandingkan dengan kelompok siswa yang belajar menggunakan model Learning Cycle berbeda secara signifikan, apabila masing-masing memiliki konsep diri yang berbeda.

Pada kelompok siswa yang memiliki konsep diri negatif, model Contextual Teaching and Learning lebih baik dibandingkan dengan model Learning Cycle. Hasil ini menandakan bahwa bagi siswa yang memiliki 
pandangan atau konsep dirinya yang negatif dapat mempengaruhi sekaligus dapat meningkatkan hasil belajar IPA.

Bagi siswa yang memiliki keyakinan dan konsep diri secara negatif maka pandangan dan keyakinan tentang kebenaran, rasa percaya dirinya bahwa mereka juga mampu melakukan sesuatu itu secara mudah dan mampu untuk melakukan sesuatu itu benar, juga rendah. Hal ini menyebabkan kreativitas mereka untuk membuat suatu konsep, menghubungkan konsep menjadi suatu pemahaman yang baru menurun sehingga lebih lama dalam proses berfikirnya. Hal ini membuat mereka sulit untuk mengolah konsep pengetahuan yang mereka peroleh untuk menjadi suatu pengetahuan baru sehingga kemampuan dalam menalar pada kelompok ini juga tidak akan optimal. Hal ini sesuai dengan apa yang disampaikan oleh Bandura (1999) bahwa seseorang dengan tingkat kemampuan keberhasilan yang rendah ditandai dengan aspirasi dan komitmen yang lemah sehingga akan menghindar dari tugas-tugas yang sulit.

Pada model Learning Cycle siswa diminta untuk dapat mengolah informasi yang diperolehnya melalui fase-fase atau tahapan tertentu sehingga dapat menjadi suatu pengetahuan baru yang diharapkan melekat dalam ingatan mereka. Karena pada kelompok siswa yang memiliki konsep diri negatif juga akan memiliki motivasi yang kurang baik yang pada akhirnya mempengaruhi dalam memberikan penalaran sebagai wujud dari hasil belajarnya. Siswa yang memiliki motivasi yang rendah akan berimplikasi terhadap rendahnya keinginan untuk mengikuti pembelajaran yang baik sehingga mereka juga akan mengalami kesulitan dalam menyelesaikan soal tes yang diberikan.

Selain itu siswa yang memiliki konsep diri negatif kepercayaan dirinya akan menjadi berkurang dan rasa takut terhadap kegagalan menjadi tinggi sehingga hal ini akan menghambat kemampuan siswa dalam hal memproses informasi. Sebagaimana yang diungkapkan Arends bahwa setiap siswa memiliki cara memproses informasi yang berbeda dan preferensi cara belajar yang berbeda pula. Untuk itu dipersiapkan suatu model pembelajaran yang baik yang memiliki kemampuan analitik yang kuat dan lebih banyak memantau pemrosesan informasi Arends, 2008).

Pada sisi lain model pembelajaran Contextual Teaching and Learning dan memiliki konsep diri negatif mendapat pembelajaran yang memiliki pola yang selalu sama yaitu guru menjelaskan materi pelajaran dengan memberi beberapa pertanyaan untuk mengingat pengetahuan yang sudah ada pada siswa lalu dilanjutkan dengan pemberian tugas yang relevan dengan kehidupan seharihari mereka dan menuntut mereka untuk selalu mampu mengaitkan kehidupan nyata di lingkungannya dengan baik. Bagi siswa yang memiliki konsep diri yang negatif maka model pembelajaran yang biasa dilakukannya akan membuat mereka nyaman sehingga kemampuan dalam hal menalar siswa yang diberi model pembelajaran tersebut menjadi lebih tinggi jika dibadingkan dengan kelompok siswa yang diberi model Learning Cycle yang membutuhkan tahapan atau proses berfikir.

Dengan demikian agar pelaksanaan model pembelajaran Learning Cycle dapat berlangsung secara efektif pada kelompok siswa yang memiliki konsep diri yang negatif, harus dilakukan dengan menguatkan motivasi belajar serta melakukan tindakan-tindakan yang mampu meningkatkan konsep diri siswa 
sehingga akan mempengaruhi usaha peningkatan kemampuan dalam berfikir atau kemampuan menalar oleh siswa melalui model Learning Cycle.

Perlu disadari bahwa penelitian ini memiliki banyak keterbatasan yang ditinjau dari beberapa faktor sebagai berikut. Pertama, penelitian ini membatasi diri pada variabel bebas model pembelajaran, yaitu Learning Cycle dan Contextual Teaching and Learning; dan variabel atribut yaitu konsep diri secata positif dan negatif; serta pengaruhnya terhadap hasil belajar IPA sebagai variabel terikat. Kedua, instrumen yang digunakan dalam penelitian ini disusun sendiri oleh peneliti, kemudian melalui uji coba instrumen sehingga terdeteksi butir-butir tes mana yang valid dan mana yang reliabel. Sehingga butir-butir tes yang tidak valid tidak dapat digunakan untuk menjaring data hasil belajar siswa. Ketiga, masih banyaknya keterbatasan serta kelemahan yang lain bagi peneliti maka diperlukan penelitian lebih lanjut bagi pihak-pihak yang berminat, karena selama penelitin ini sedang berlangsung yang terjadi pada kelas yang dieksperimenkan ataupun kelas kontrol tersebut kondisinya yang tidak sama pada masing-masing kelompok siswa yang memiliki gambaran atau konsep diri yang berbeda, sehingga akan menghasilkan suatu pembelajaran yang kurang optimal pada setiap pertemuan dan akhirnya akan berpengaruh pada skor akhir atau hasil belajar IPA.

\section{KESIMPULAN}

\section{A. Kesimpulan}

Berdasarkan hasil pengujian hipotesis pada Bab IV, maka hasil penelitian ini dapat disimpulkan sebagai berikut:

1. Hasil belajar IPA siswa yang belajar dengan model pembelajaran Learning Cycle lebih tinggi daripada hasil belajar IPA siswa yang belajar dengan model pembelajaran Contextual Teaching and Learning. Dengan demikian untuk meningkatkan hasil belajar IPA dapat dilakukan dengan menggunakan model pembelajaran Learning Cycle.

2. Terdapat pengaruh interaksi penggunaan model pembelajaran Learning Cycle dan konsep diri siswa terhadap hasil belajar IPA. Dengan demikian dalam meningkatkan hasil belajar IPA dapat dilakukan dengan menyesuaikan antara model pembelajaran yang digunakan dan jenis konsep diri yang dimiliki siswa.

3. Pada kelompok siswa yang memiliki konsep diri positif, hasil belajar IPA siswa yang belajar menggunakan model pembelajaran Learning Cycle lebih tinggi daripada siswa yang belajar menggunakan model pembelajaran Contextual Teaching and Learning. Dengan demikian untuk meningkatkan hasil belajar IPA siswa yang memiliki konsep diri positif dapat diterapkan dengan menggunakan model pembelajaran Learning Cycle.

4. Pada kelompok siswa yang memiliki konsep diri negatif, hasil belajar IPA siswa yang belajar dengan model pembelajaran Learning Cycle lebih rendah daripada siswa yang belajar menggunakan model pembelajaran Contextual Teaching and Learning. Dengan demikian untuk meningkatkan hasil belajar IPA siswa yang memiliki konsep diri negatif dapat diterapkan dengan menggunakan model pembelajaran Contextual Teaching and Learning. 


\section{DAFTAR PUSTAKA}

Arends, Richard I. Learning to Teach, terjemahan: HP. Soetjipto dan SM Soetjipto. Yogyakarta: Pustaka Pelajar, 2008.

Bandura, Albert. Self Efficay in Changing Societies. New York: Cambridge University Press, 1999.

Carin, Arthur A., Teaching Modern Science, 7 th ed. New York: Macmillan Publishing Company, 2001.

Murwani, Santosa. Statistika Terapan: Teknik Analisa Data. Jakarta: Program Pascasarjana UNJ. 2005.

Naga, Dali Santun. Probabilitas dan Skor pada Hipotesis Statistika. Jakarta: UPT Penerbitan Universitas Tarumanegara, 2008.

Suyono dan Hariyanto. Belajar dan Pembelajaran: Teori dan Konsep Dasar. Bandung: : PT Remaja Rosdakarya, 2011. 